\title{
Comparison of surface iodination methods by electron microscopic autoradiography applied in vitro to different life-stages of Dipetalonema viteae (Filarioidea)
}

\author{
W. BASCHONG and W. RUDIN \\ Swiss Tropical Institute, CH-4051 Basel, Switzerland
}

(Accepted 27 April 1982)

\section{S UM M A R Y}

Different stages of Dipetalonema viteae (males, females, microfilariae, and 3rd-stage larvae) have been iodinated in vitro under physiological conditions by chloroglycoluril, lactoperoxidase or chloramine $\mathbf{T}$. The concentrations of the catalysts were correlated with the viability of the worms. Localization of the label with the different iodination methods had been visualized by electron microscopical autoradiography. Chloroglycoluril-mediated iodination is predominantly localized on the filarial cuticle. Lactoperoxidase-catalysed iodination is less specific and chloramine $\mathrm{T}$ catalyses iodination in a gradient decreasing from the cuticle to inner structures. It is necessary to visualize the labelling by electron microscopical autoradiography prior to biochemical and immunological experiments to avoid the extraction of structuresiodinated by leakage of the catalyst into sub-cuticular regions.

\section{IN TRODUCTION}

Immunological control of parasitic helminths depends mainly on the structure of the contact site with the host namely, the cuticle (Lumsden, 1975, Mackenzie, Preston \& Ogilvie, 1978, Ogilvie, Philipp, Jungery, Maizels, Worms \& Parkhouse, 1981). Surface antigen characterization and isolation has preferentially been carried out by using ${ }^{125}$ I as a tracer. Philipp, Parkhouse \& Ogilvie (1980) and Parkhouse, Philipp \& Ogilivie (1981), used chloramine $T$ and lactoperoxidase as catalysts for iodination of Trichinella spiralis. Chloroglycoluril was applied to Onchocerca gibsoni by Forsyth, Copeman, Abbot, Andress \& Mitchell (1981). The only comparison of different catalysts has been reported by Hayunga, Murell, Taylor \& Vannier (1979) using Schistosoma mansoni. Since the composition of the tegument of the helminths is largely unknown it is difficult to attribute the radioactive label to a specific surface protein. This is in contrast to the work of Markwell \& Fox (1978) who used Sendai and Newcastle disease viruses to compare the specificity of iodination with different catalysts on well-characterized viral coat proteins. As a result they found that CGU-mediated iodination is slightly preferable to that by lactoperoxidase.

Reprint requests to: Dr W. Rudin, Swiss Tropical Institute, Socinstrasse 57, CH-4051 Basel/Switzerland. 
The aim of our work was to evaluate with electron microscopical autoradiography the surface specificity of commonly used iodination methods with emphasis on chloroglycoluril applied to different stages of the same species.

\section{MATERIALS AND METHODS \\ Host-parasite system}

The filarial parasite Dipetalonema viteae was maintained in the jird, Meriones unguiculatus and the soft tick, Ornithodorus moubata as described by Worms, Terry \& Terry (1961). Male golden hamsters (60-80 g) came from a randomly bred colony (strain LAKZ, Institut für Zuchthygiene der Universität Zürich, Switzerland).

Adult worms were harvested from hamsters according to the method described by Baschong, Tanner, Betschart, Rudin \& Weiss (1982), 3rd-stage larvae $\left(L_{3}\right)$ from infected ticks by the method of Gass, Tanner \& Weiss (1979), and microfilariae from in vitro-maintained female worms after Weiss \& Tanner (1979).

\section{Iodination (Table 1)}

$\mathrm{Na}^{125} \mathrm{I}$ (carrier-free, EIR Würenlingen, Switzerland) was reconstituted in $0 \cdot 15 \mathrm{M}$ phosphate-buffered saline (PBS), $\mathrm{pH} 7 \cdot 2$, to an activity of $20 \mathrm{mCi} / \mathrm{ml}$. All iodination tests were carried out in a volume of $0.5 \mathrm{ml}$ PBS at room temperature. Chloramine $\mathbf{T}$ and lactoperoxidase catalysed iodinations were performed in $12 \mathrm{ml}$ vol. glass centrifuge tubes and chloroglycoluril-mediated iodinations in borosilicate tubes (see below).

Table 1. Experimental conditions for the in vitro labelling of different Dipetalonema

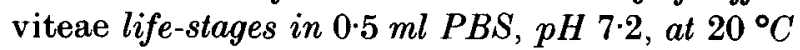

\begin{tabular}{|c|c|c|c|c|c|c|c|}
\hline \multirow{2}{*}{$\begin{array}{c}\text { Number and stage } \\
\text { of parasites }\end{array}$} & \multicolumn{2}{|c|}{ Chloroglycoluril* } & \multicolumn{2}{|c|}{ Chloramine $\mathbf{T} \dagger$} & \multicolumn{2}{|c|}{ Lactoperoxidase $\ddagger$} & \multirow{2}{*}{$\begin{array}{r}\text { Control* } \\
\left(\mu \mathrm{Ci} \mathrm{Na}{ }^{12}\right.\end{array}$} \\
\hline & $\mu \mathrm{g}$ & $\mu \mathrm{Ci} \mathrm{Na}{ }^{125} \mathrm{I}$ & ng & $\mu \mathrm{Ci} \mathrm{Na}^{125} \mathrm{I}$ & pmole & $\mu \mathrm{Ci} \mathrm{Na}{ }^{125} \mathrm{I}$ & \\
\hline 2 Females & $\left\{\begin{array}{r}10 \\
100\end{array}\right.$ & $\left.\begin{array}{l}200 \\
200\end{array}\right\}$ & 125 & 200 & 50 & 200 & 200 \\
\hline 4-5 Males & $\left\{\begin{array}{r}10 \\
100\end{array}\right.$ & $\left.\begin{array}{l}100 \\
100\end{array}\right\}$ & 125 & 100 & 50 & 100 & 200 \\
\hline 50000 Microfilariae & $100 \S$ & 200 & $\left\{\begin{array}{r}125 \\
1250\end{array}\right.$ & $\left.\begin{array}{l}200 \\
500\end{array}\right\}$ & \multicolumn{2}{|c|}{ not done } & 500 \\
\hline 1000 Third-stage larvae & $\left\{\begin{array}{c}5 \\
100 \S\end{array}\right.$ & $\left.\begin{array}{l}500 \\
200\end{array}\right\}$ & 125 & 200 & 50 & 200 & 500 \\
\hline
\end{tabular}

\section{Chloramine $T$}

$\mathrm{Na}{ }^{125} \mathrm{I}$ and chloramine $\mathrm{T}$ were reacted with the parasites for $3 \mathrm{~min}$ (McConahey \& Dixon, 1980). L-tyrosine (Merck, Darmstadt, BRD) at a concen- 
tration of $15 \mathrm{~mm}$ in $\mathrm{PBS} / \mathrm{mCi}$ of $\mathrm{Na}^{125} \mathrm{I}$ was added in a final volume of $5 \mathrm{ml}$. After $1 \mathrm{~min}$, adult $D$. viteae were transferred in a new tube and washed twice with $5 \mathrm{ml}$ of $5 \mathrm{~mm} \mathrm{Na} \mathrm{I}$ in PBS (pre-warmed to $37^{\circ} \mathrm{C}$ ). Microfilariae and $\mathrm{L}_{3}$ larvae were centrifuged for $10 \mathrm{~min}$ at $300 \mathrm{~g}$ after addition of $\mathrm{L}$-tyrosine in PBS, the supernatant fluids were discarded and the pellets washed twice with $5 \mathrm{ml}$ of PBS/ Na I solution. Until EM-fixation the worms were kept in RPMI at $37^{\circ} \mathrm{C}$.

\section{Lactoperoxidase}

Lactoperoxidase-mediated iodination was initiated by adding $2 \mu \mathrm{l}$ of $\mathrm{H}_{2} \mathrm{O}_{2}(33 \%)$ freshly diluted $1: 1000$ after 1, 2 and $3 \mathrm{~min}$ to the reaction mixture (Morrison, 1980) After $4 \mathrm{~min}$ the reaction was stopped with tyrosine.

\section{Chloroglycoluril}

Chloroglycoluril-mediated iodinations (Fraker \& Speck, 1978; Markwell \& Fox, 1978) were carried out in round-bottomed borosilicate tubes ( $13 \times 100 \mathrm{~mm}$, Corning, New York, USA) coated with 1,3,4,6-tetrachloro,3 $\alpha, 6 \alpha$-diphenyl-glycoluril (trade name IODO-GENTM, Pierce Chemicals Co., Rockford, Illinois USA) dissolved in $\mathrm{CH}_{2} \mathrm{Cl}_{2}$, by drying the solution under a stream of nitrogen. Immediately before use the coated tubes were rinsed with iodination buffer to remove any flakes of the catalyst.

The biological material was placed in $500 \mu \mathrm{l}$ of PBS in coated glass tubes and, after addition of the iodine, were incubated for $10 \mathrm{~min}$ with occasional stirring. $\mathrm{L}$-tyrosine at a concentration of $15 \mathrm{~mm}$ in $\mathrm{PBS} / \mathrm{mCi}$ was added to a total volume of $5 \mathrm{ml}$ and after $1 \mathrm{~min}$ adult worms were transferred to $5 \mathrm{ml}$ of pre-warmed $5 \mathrm{~mm}$ $\mathrm{NaI}$ in PBS and washed as above. Iodination of microfilariae and 3rd-stage larvae was stopped with $15 \mathrm{~mm} L$-tyrosine/mCi suspended in $2 \mathrm{ml}$ of PBS by incubation for $1 \mathrm{~min}$. The contents of the reaction vial were transferred to a $12 \mathrm{ml}$ vol. glass centrifuge tube. To this tube $2.5 \mathrm{ml}$ of PBS was added. After centrifugation the supernatant fluid was discarded and the remainder washed twice as above.

\section{Electronmicroscopy and autoradiography}

Two hours after labelling, the worms were fixed with $4 \%(v / v)$ glutaraldehyde in $0 \cdot 1 \mathrm{M} \mathrm{Na-cacodylate} \mathrm{buffer}(\mathrm{pH} 7 \cdot 4)$ for $90 \mathrm{~min}$ at room temperature. After fixation for $30 \mathrm{~min}$, adult worms were cut into pieces (1-3 $\mathrm{mm}$ length) and further processed for EM in specimen tubes. Third-stage larvae were processed either as clumps formed by living larvae or by centrifugation in $10 \% \mathrm{BSA}$ followed by cross-linking with glutaraldehyde or as free-floating worms in cavity blocks. Preparation of microfilariae and processing of all specimens after fixation was done as described by Rudin, Tanner, Bauer \& Weiss (1980).

Ultrathin sections $(50-80 \mathrm{~nm})$ were cut on a LKB Ultratome III and transferred to parlodion-coated grids. For electron mciroscopical autoradiography the loop method of Bienz (1977) was used. The Ilford L4 coated grids were exposed at $4{ }^{\circ} \mathrm{C}$ in a dry atmosphere for 14-133 days. For the first chloroglycoluril series the exposure time was estimated approximately by light microscopical autoradiography 
on semi-thin sections. For electron microscopy the physical development and poststaining of the grids was done according to Bienz (1977).

\section{RESULTS}

Motility of untreated control worms was taken as a parameter to assess the viability of the worms. Reagents were applied at concentrations at which no change in motility could be detected by eye (for males and females) or microscopically (for 3rd-stage larvae and microfilariae) until fixation for electron microscopy. Na I and tyrosine had no effect on the motility of any stage, whereas chloroglycoluril and chloramine $\mathbf{T}$ at high concentrations were toxic for the worms. Lactoperoxidase at the concentrations used did not seem to affect the viability of the organisms (Table 1).

\section{Chloroglycoluril iodination}

Chloroglycoluril-mediated iodination of adult females and males showed cuticular specificity at both concentrations used (Pl. 1 A, B). The catalyst concentration (10 or $100 \mu \mathrm{g} /$ tube) did not significantly influence the specificity and intensity of the labelling. At a concentration of $100 \mu \mathrm{g}$, the incubation of male worms was reduced to $5 \mathrm{~min}$. Longer exposure to the catalyst immobilized the worms. The shorter reaction time resulted in a lower intensity of labelling.

Iodination of $D$. viteae 3rd-stage larvae and microfilariae was performed at the lethal concentration of $100 \mu \mathrm{g}$ of chloroglycoluril/tube. In both larval stages this lethal concentration resulted in a loss of specificity $(\mathrm{Pl}, 1 \mathrm{C}, \mathrm{D})$ or cuticular labelling. Third-stage larvae iodinated with $10 \mu \mathrm{g}$ of catalyst/tube retained their motility and showed efficient surface labelling of the cuticle (Pl. $1 \mathrm{D}$ ).

As a control, the 4 stages were incubated for $10 \mathrm{~min}$ with the appropriate amount of $\mathrm{Na}^{125} \mathrm{I}$ without any catalyst. No detectable iodination occured in any of the 4 stages (Pl. 1 F). Addition of tyrosine to the organisms after iodination did not result in any difference in labelling by autoradiography compared to those without tyrosine. Thus, a significant incorporation of radioactive tyrosine can be excluded.

\section{Lactoperoxidase iodination}

Lactoperoxidase-mediated iodination ( 50 pmole lactoperoxidase) labelled less intensively than chloroglycoluril iodination. This was expressed as a longer exposure time for the autoradiographs to reach a sufficient grain density. Adult D. viteae showed rather specific cuticular labelling (Pl. 2A) with occasional scattering into inner structures.

As in the adult worms the intensity of lactoperoxidase-catalysed iodination of 3rd-stage larvae (Pl. 2B) was at a low level compared to the chloroglycoluril reaction. In contrast to the adult worms the label was not concentrated on the cuticle.

\section{Chloramine T iodination}

At chloramine $\mathrm{T}$ concentrations which did not influence the motility of the worms (125 $\mathrm{ng}$ for males, females and 3rd-stage larvae, $1250 \mathrm{ng}$ for microfilariae) 
the least specific and weakest iodination occurred in our experiments. Adult male and female $D$. viteae showed an even distribution of the marker over the whole filarial profile (Pl. 2C(i) or a density gradient from the surface to inner structures of the worm (Pl. 2C(ii)). In no experiment with microfilariae and 3rd-stage larvae could a preference for the cuticle be assigned (Pl. 2D).

\section{DISCUSSION}

The specificity of labelling of helminths as a tool to trace surface material of the parasites depends on the nature of the surface covering the species under investigation and on the method and conditions of iodination. The $D$. viteae system allowed investigation of iodination of cuticles of different thickness and antigenically different structures (Weiss \& Tanner, 1981).

We limited our studies to the iodination of different life-stages of $D$. viteae by chloramine $\mathrm{T}$, lactoperoxidase and chloroglycoluril using methods previously applied to labelling of antigenic surface material as recently published (Forsyth et al. 1981 ; Parkhouse et al. 1981; Philipp et al. 1980).

Our aim was to label living organisms and localize surface staining by electron microscopy. Worms which died during iodination using chloroglycoluril as catalyst showed a less specific surface localization of the label than living ones. This could be explained by assuming that the relatively low solubility of chloroglycoluril $\left(8 \times 10^{-6} \mathrm{M}\right.$, Fraker \& Speck (1978)) results in its accumulation in the hydrophobic layer of the cuticle. To avoid possible toxic effects of $\mathrm{Na}_{2} \mathrm{~S}_{2} \mathrm{O}_{5}$ (for chloramine $\mathrm{T}$ ) or enzyme inhibitors (for lactoperoxidase), L-tyrosine was added in excess to terminate the reaction by binding any free activated iodine. In the case of chloroglycoluril, L-tyrosine was added to produce similar conditions in all three labelling procedures. Chloramine $\mathrm{T}$ and chloroglycoluril at high concentrations seem to interfere with the motility of almost all stages of $D$. viteae. Microfilariae did not show signs of lower motility at a concentration of $1250 \mathrm{ng}$ in $0.5 \mathrm{ml} \mathrm{PBS}$, a fact which might be due to a rather different structure of the cuticle. In the case of lactoperoxidase, only the concentration of $\mathrm{H}_{2} \mathrm{O}_{2}$ seemed to interfere with the viability of microfilariae and 3rd-stage larvae.

Chloramine $\mathbf{T}$, the small water-soluble catalyst might be adsorbed to the cuticle or even incorporated through the cuticle into inner structures; a fact which could explain the low specificity of this catalyst. Lactoperoxidase is a large molecule which will not penetrate the membrane as easily (Philips \& Morrison, 1971) and thus catalyses surface iodination more specifically. Chloroglycoluril creates active iodine at the surface of the solid catalyst and/or by the few molecules soluble in the reaction solution. The possibility that active iodine is incorporated is therefore low.

Recently, Schlager (1979) reported that lactoperoxidase does not only mediate classical iodination of tyrosine and histidine in proteins but also certain lipids. The mechanism of the reaction remains unclear. The extraction of the PBS and PBS-NaOH treated sediments of $D$. viteae homogenates (Baschong et al. 1982) by $n$-butanol resulted in a concentration of approximately $10 \%$ of total radioactivity in the butanol layer (unpublished results), a fact which leads to the assumption that chloroglycoluril-mediated iodination is capable of labelling structures with lipophilic character. 
It seems that the thick cuticle of females is the best barrier for the marker and the catalyst during the iodination procedure. This results in a more or less surface-specific, lactoperoxidase-mediated iodination compared to other stages and the highest resistance against toxic effects of the catalysts. In the larval stages, the cuticle is approximately 10 times thinner and there is no surface specificity after lactoperoxidase-mediated labelling. The loss of specificity with higher chloroglycoluril concentrations might indicate a higher sensitivity to the toxic effect of the catalyst as compared to adult worms.

The physical development of the autoradiographs with Agfa Gevaert Developer (Kopriwa, 1975) produces compact, rounded silver deposits whose size can be influenced by the developing time, resulting in relatively good resolution. Nevertheless, a certain dimension of the structures is required to attribute the label to specific parts of the cuticle. The successful labelling of female and male worms allows us to associate the marker on the autoradiographs with parts of the cortical layer of the nematode cuticle (Bird, 1980). The thin cuticles of microfilariae and 3rd-stage larvae, however, exclude localization of the marker within the cuticle.

In conclusion, it can be said that for the $D$. viteae system and probably other filarial systems, chloroglycoluril at low concentrations seems to be the most useful of the catalysts tested for cuticular iodination.

This study was supported by a grant from the Swiss National Science Foundation (grant no. 3.267.78). In addition, W.B. was supported by the 'Emilia Guggenheim - Schnurr Stiftung der Naturforschenden Gesellschaft in Basel', the 'Geigy Jubiläums-Stiftung' and the 'Fonds zur Förderung von Lehre und Forschung'. The helpful suggestions and critical discussion of the manuscript by $\mathrm{Dr} N$. Weiss and Dr B. Betschart are gratefully acknowledged. We thank Mrs E. Fluri, Mrs M. Hofmann, Miss R. Rufener and Mrs H. Ziegler for expert technical assistance.

\section{RE FER E N C ES}

Baschong, W., Tanner, M., Betschart, B., Rudin, W. \& Weiss, N. (1982). Dipetalonema viteae (Filarioidea): Extraction and immunogenicity of cuticular antigens from adult female worms. Journal of Experimental Parasitology 53, 262-9.

Bienz, K. A. (1977). Techniques and applications of autoradiography in the light and electron microscope. Microscopica Acta 79, 1-22.

BIRD, A. F. (1980). The nematode cuticle and its surface. In Nematodes as Biological Models, vol. 2 (ed. B. M. Zuckermann), pp. 213-36. New York and London: Academic Press.

Forsyth, K. P., Copeman, D. B., Aвbot, R. F., Andress, R. F. \& Mitchell, G. F. (1981). Identification of radioiodinated cuticular proteins and antigens of Onchocerca gibsoni microfilariae. Acta Tropica 38, 329-42.

Fraker, P. J. \& SPECK, J. C. JR. (1978). Protein and cell membrane iodinations with a sparingly soluble chloramide, 1,3,4,6-tetrachloro-3 $\alpha, 6 \alpha$-diphenylglycoluril. Biochemical and Biophysical Research Communications 80, 849-57.

Gass, R. F., TANner, M. \& Weiss, N. (1979). Development of Dipetalonema viteae third stage larvae (Nematoda; Filarioidea) in micropore chambers implanted into jirds, hamsters, normal and immunized mice. Zeitschrift für Parasitenkunde 61, 73-82.

Hayunga, E. G., Murell, K. D., Taylor, D. W. \& Vannier, W. E. (1979). Isolation and characterization of surface antigens from Schistosoma mansoni. I. Evaluation of techniques for radioisotope labelling of surface proteins from adult worms. Journal of Parasitology 65, $488-96$.

Kopriwa, B. M. (1975). A comparison of various procedures for fine grain development in electron microscopic radioautography. Histochemie 44, 201-24.

LUMSDEN, D. L. (1975). Surface ultrastucture and cytochemistry of parasitic helminths. Experimental Parasitology 37, 267-339.

MARkwell, M. A. K. \& Fox, C. F. (1978). Surface specific iodination of membrane proteins of 

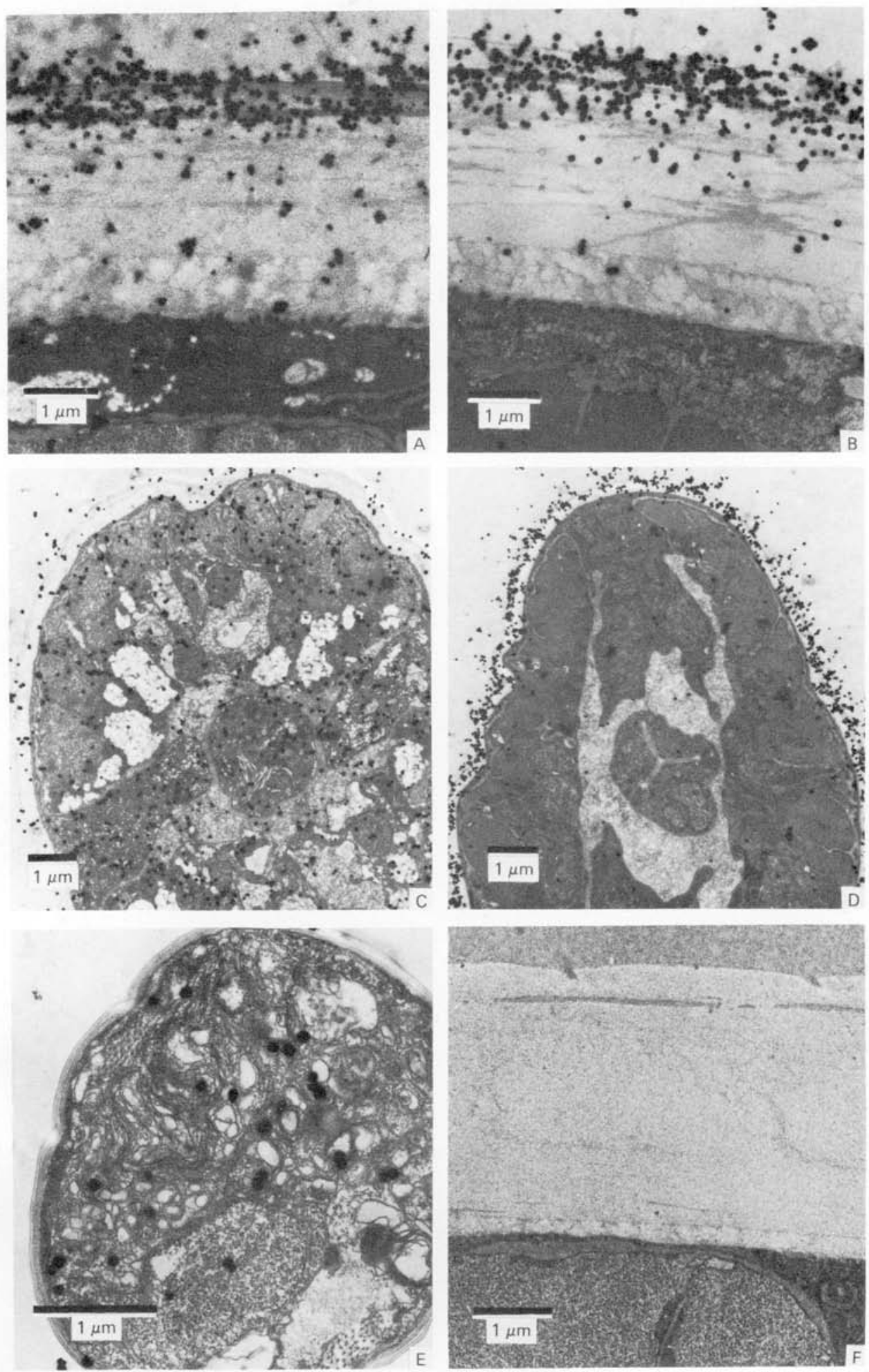

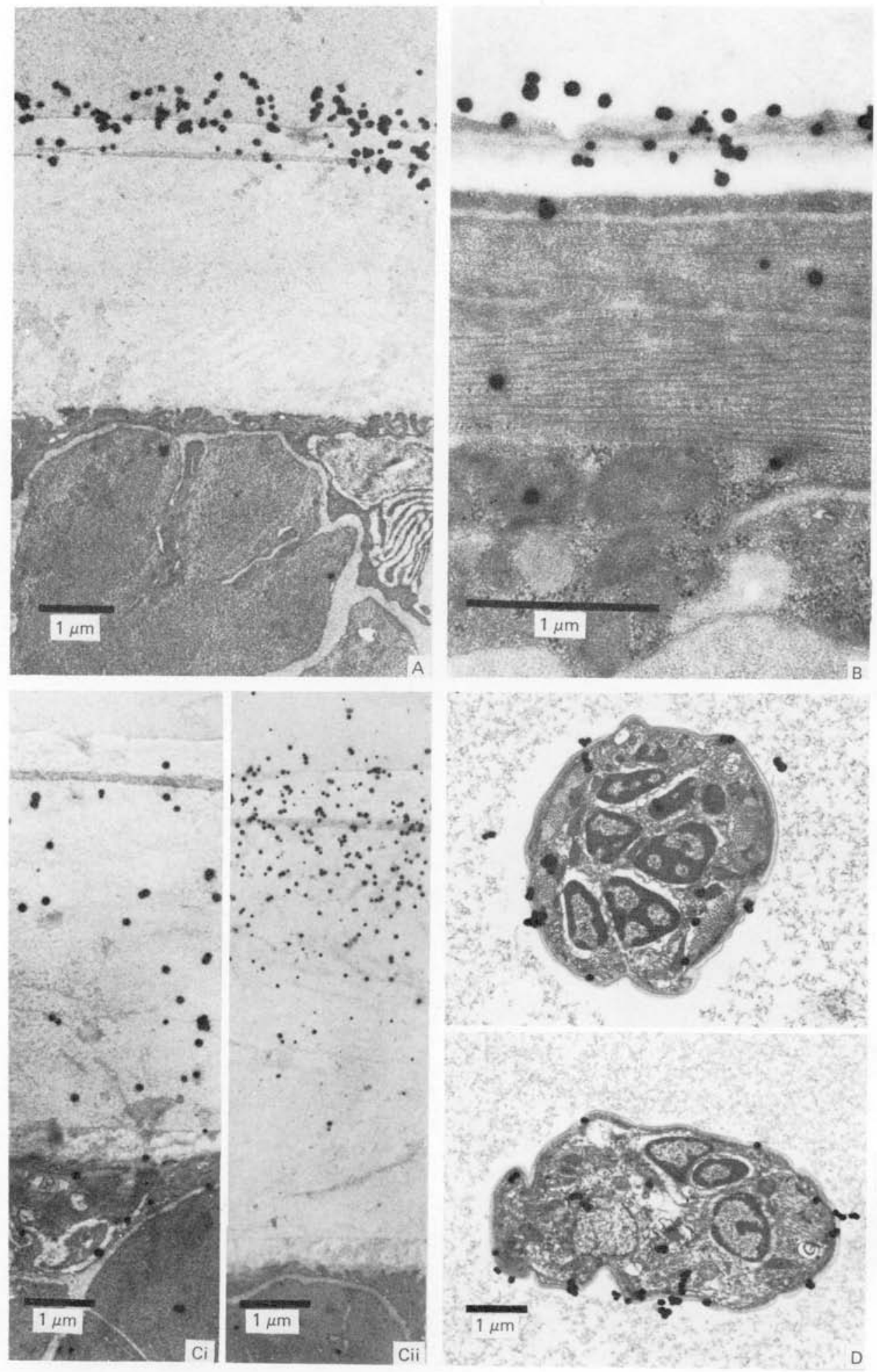

\section{W. BASCHONG AND W. RUDIN}


viruses and eucaryotic cells using 1,3,4,6-tetrachloro-3 $\alpha, 6 \alpha$-diphenylglycoluril. Biochemistry 17, 4807-17.

MoConahey, P. J. \& Dixon, F. J. (1980). Radioiodination of proteins by use of the chloramine T method. In Methods of Enzymology, vol. 70 (ed. H. van Vunakis and J. J. Langone), pp. 201-13. New York, London, Toronto, Sydney and San Francisco: Academic Press.

Mackenzie, C. D., Preston, P. M. \& Ogilvie, B. M. (1978). Immunological properties of the surface of parasitic nematodes. Nature, London 276, 826-8.

MorRison, M. (1980). Lactoperoxidase catalyzed iodination as a tool for investigation of proteins. In Methods of Enzymology, vol. 70 (ed. H. van Vunakis and J. J. Langone), pp. 214-20. New York, London, Toronto, Sydney and San Francisco: Academic Press.

Oallvie, B. M., Philipp, M., Jungery, M., Maizels, R. M., Worms, M. J. \& Parkhouse, R. M. E. (1981). The surface of nematodes and the immune response of the host. In Proceedings of the 3rd Janssen Symposium, Biochemistry of Parasites and Host-Parasite Relationships (ed. M. Van der Bosch), pp. 99-104. Amsterdam : Elsevier.

Parkhouse, R. M. E., Philipp, M. \& Ogilvie, B. M. (1981). Characterization of surface antigens of Trichinella spiralis infective larvae. Parasite Immunology 3, 339-52.

Philipp, M., Parkhouse, R. M. E. \& Oallvie, B. M. (1980). Changing proteins on the surface of a parasitic nematode. Nature, London 287, 538-40.

Phillips, D. R. \& Morrison, M. (1971). Exposed protein on the intact human erythrocyte. Biochemistry 10, 1766-71.

Rudin, W., Tanner, M., Bauer, P. \& Weiss, N. (1980). Studies on Dipetalonema viteae (Filarioidea). 5. Ultrastructural aspects of the antibody-dependent cell-mediated destruction of microfilariae. Tropenmedizin und Parasitologie 31, 194-200.

Schlager, S. I. (1979). Specific ${ }^{125}$ I-iodination of cell surface lipids: Plasma membrane alterations induced during humorale immune attack. Journal of Immunology 123, 2108-13.

Weiss, N. \& Tanner, M. (1979). Studies on Dipetalonema viteae (Filarioidea). 3. Antibodydependent cell mediated destruction of microfilariae in vivo. Tropenmedizin und Parasitologie 30, 73-80.

WeISS, N. \& TANNER, M. (1981). Experimental filariasis in the syrian hamster; immunological aspects of complex host-parasite interactions. In Hamster Immune Responses in Infectious and Oncologic Diseases (ed. J. Wayne Streilein, D. A. Hart, J. Stein-Streilein, W. R. Duncan and R. E. Billingham), pp. 253-265. New York: Plenum Publishing Corporation.

Worms, M. J., Terry, R. J. \& Terry, A. (1961). Dipetalonema witei, filarial parasite of the jird, Meriones libycus. I. Maintenance in the laboratory. Journal of Parasitology 47, 963-70.

\section{EXPLANATION OF PLATES}

Pla t e 1

A-E. Chloroglycoluril (CGU)-mediated iodination of Dipetalonema viteae.

A. Female, $100 \mu \mathrm{g} \mathrm{CGU} / 200 \mu \mathrm{Ci} \mathrm{Na}{ }^{125} \mathrm{I}$, exposure time 14 days.

B. Female, $10 \mu \mathrm{g} \mathrm{CGU} / 200 \mu \mathrm{Ci} \mathrm{Na}{ }^{125} \mathrm{I}$, exposure time 21 days.

C. Third-stage larva, $100 \mu \mathrm{g} \mathrm{CGU} / 200 \mu \mathrm{Ci} \mathrm{Na}{ }^{125} \mathrm{I}$, exposure time 16 days.

D. Third-stage larva, $5 \mu \mathrm{g} \mathrm{CGU} / 500 \mu \mathrm{Ci} \mathrm{Na}{ }^{125} \mathrm{I}$, exposure tịme 28 days.

E. Microfilaria, $100 \mu \mathrm{g} \mathrm{CGU} / 200 \mu \mathrm{Ci} \mathrm{Na}{ }^{125} \mathrm{I}$, exposure time 16 days.

F. Male $D$. viteae incubated with $200 \mu \mathrm{Ci} \mathrm{Na}{ }^{125} \mathrm{I}$ without catalyst, exposure time 21 days.

\section{Plate 2}

A and B. Lactoperoxidase (LPO)-mediated iodination of Dipetalonema viteae.

A. Male, 50 pmole $\mathrm{LPO} / 100 \mu \mathrm{Ci} \mathrm{Na}{ }^{125} \mathrm{I}$, exposure time 51 days.

B. Third-stage larva, 50 pmole LPO/200 $\mu \mathrm{Ci} \mathrm{Na}{ }^{125}$, exposure time 27 days.

$\mathrm{C}$ and $\mathrm{D}$. Chloramine $\mathrm{T}(\mathrm{Chl} \mathrm{T})$-mediated iodination of $D$. viteae.

C. (i) Male, $125 \mathrm{ng} \mathrm{Chl} \mathrm{T} / 100 \mu \mathrm{Ci} \mathrm{Na}{ }^{125} \mathrm{I}$, exposure time 21 days.

C. (ii) Male, $125 \mathrm{ng} \mathrm{Chl} \mathrm{T} / 100 \mu \mathrm{Ci} \mathrm{Na}{ }^{125} \mathrm{I}$, exposure time 133 days.

D. Microfilariae, $125 \mathrm{ng} \mathrm{Chl} \mathrm{T} / 100 \mu \mathrm{Ci} \mathrm{Na}{ }^{125} \mathrm{I}$, exposure time 27 days. 